\title{
Glucocorticoid Receptor Expression in the Spinal Cord after Traumatic Injury in Adult Rats
}

\author{
Ping Yan, ${ }^{1}$ Jian Xu, ${ }^{2}$ Qun Li, ${ }^{1,2}$ Sawei Chen, ${ }^{2}$ Gyeong-Moon Kim, ${ }^{2}$ Chung Y. Hsu, ${ }^{2}$ and Xiao Ming $\mathbf{X u}^{1}$ \\ ${ }^{1}$ Department of Anatomy and Neurobiology, St. Louis University School of Medicine, St. Louis, Missouri 63104, and \\ 2Department of Neurology, Washington University School of Medicine, St. Louis, Missouri 63110
}

\begin{abstract}
Methylprednisolone (MP), a glucocorticoid, is the only effective therapeutic agent used in the clinical treatment of acute spinal cord injury (SCl). MP given within $8 \mathrm{hr}$ after $\mathrm{SCl}$ significantly improves neurological function. Although the glucocorticoid receptor (GR) is suggested to mediate MP actions, limited knowledge is available on its expression and possible function after SCl. Presently, the expression of GR was studied in a weight-drop $\mathrm{SCl}$ model in adult rats. Immunohistochemistry and Western blot analysis revealed an increase in GR protein expression as early as $15 \mathrm{~min}$ after injury. GR expression sharply increased at $4 \mathrm{hr}$ (22-fold), peaked at $8 \mathrm{hr}$ (56-fold), rapidly declined at $1 \mathrm{~d}$, and returned to the baseline level at and after $3 \mathrm{~d}$. During its peak expression, GR was localized in neural somata and dendrites but not in axons and their terminals. GR
\end{abstract}

Spinal cord injury(SCI) is a devastating event experienced by humans, especially young adults (Bracken et al., 1981). Methylprednisolone (MP), a potent synthetic glucocorticoid, is the only therapeutic agent proven effective in reducing neurological deficit after SCI (Bracken et al., 1990, 1992). MP is suggested to suppress lipid peroxidation and hydrolysis that destroys neuronal and microvascular membranes (Hall and Braughler, 1981, 1982; Demopoulos et al., 1982; Anderson et al., 1985; Hall, 1992). MP possesses potent anti-inflammatory actions that may also contribute to its therapeutic effects in SCI (Hsu and Dimitrijevic, 1990; Bartholdi and Schwab, 1995). The discovery that glucocorticoid receptor (GR) activation inhibits the transcriptional activity of nuclear factor- $\kappa \mathrm{B}(\mathrm{NF}-\kappa \mathrm{B})$ provides a molecular basis for the potent anti-inflammatory and immunosuppressive properties of glucocorticoids (Auphan et al., 1995; Scheinman et al., 1995). $\mathrm{NF}-\kappa \mathrm{B}$ promotes the expression of a number of key inflammatory mediators, including cytokines, inducible nitric oxide synthase, adhesive molecules, and others (Moynagh et al., 1994; DhibJalbut et al., 1995; Hall et al., 1994). Increased NF-кB binding activity after SCI has been demonstrated recently in rats (Bethea et al., 1998; Xu et al., 1998). MP suppression of NF- $\kappa$ B binding activity (Xu et al., 1998) is consistent with the contention that the therapeutic effect of MP in SCI may be related, at least in part, to its anti-inflammatory action (Hsu and Dimitrijevic, 1990).

\footnotetext{
Received March 4, 1999; revised June 7, 1999; accepted Aug. 20, 1999.

We are thankful for support from National Institute of Health Grants NS37230 and NS36350, the Paralyzed Veterans of America Spinal Cord Research Foundation, and the International Spinal Research Trust.

Correspondence should be addressed to Dr. Xiao Ming Xu, Department of Anatomy and Neurobiology, St. Louis University School of Medicine, 1402 South Grand Boulevard, St. Louis, MO 63104. E-mail: xuxm@slu.edu.

Copyright (C) 1999 Society for Neuroscience $0270-6474 / 99 / 199355-09 \$ 05.00 / 0$
}

immunoreactivity was also found in oligodendrocytes and astrocytes. Interestingly, other cell types, such as endothelial cells, were GR-negative. An increase in the binding activity of nuclear proteins to the glucocorticoid responsive element was also observed after $\mathrm{SCl}$, demonstrating a functional element of GR activation. Finally, colocalization of GR and tumor necrosis factor $\alpha$ (TNF- $\alpha$ ), an inflammatory cytokine, was observed in neurons and glial cells, consistent with MP regulation of TNF- $\alpha$ in this model. Thus, the transient expression of high levels of GR after SCl may provide new insights into the antiinflammatory action of MP.

Key words: glucocorticoid receptor; inflammation; methylprednisolone; rat; spinal cord injury; TNF- $\alpha$

Glucocorticoids transmit molecular information to neurons and glial cells in the CNS and regulate cell function. Glucocorticoids bind to intracellular GR, which in turn bind to glucocorticoid responsive element (GRE) to exert ligand-activated transcription effects (Yamamoto, 1985). Thus, glucocorticoid actions depend not only on the ligand concentration but also on the extent of GR expression. Although GR is known to be expressed in the normal CNS (Fuxe et al., 1985; Ahima and Harlan, 1990), little is known about its expression after experimental SCI. To our knowledge, post-traumatic GR activation has not been studied in animal models of SCI. This is surprising because MP has been shown repeatedly to reduce tissue damage and improve neural function in SCI animal models (Means et al., 1981; Braughler and Hall, 1982; Young and Flamm, 1982) and in clinical management of acute SCI (Bracken et al., 1990, 1992, 1997). Results from the Second National Acute Spinal Cord Injury Study (NASCIS 2) demonstrated that high doses of MP started within $8 \mathrm{hr}$ of injury resulted in improved neurological recovery (Bracken et al., 1990, 1992). MP therapy started more than $8 \mathrm{hr}$ after injury, however, not only was ineffective but was potentially detrimental to neurological recovery (Bracken and Holford, 1993). The mechanisms behind this limited therapeutic window of MP after SCI are not fully understood.

In the present study, we sought to determine the temporal and spatial patterns of GR expression, GRE transcriptional activity, and colocalization of GR and tumor necrosis factor $\alpha$ (TNF- $\alpha$ ) after SCI. Our results demonstrate that GR is expressed intensely within the first $8 \mathrm{hr}$ after SCI. The transient expression of high levels of GR after SCI may provide new insights into the antiinflammatory action of MP.

Part of this paper has been published previously in abstract form (Yan et al., 1998). 
Table 1. Animals used for each experiment

\begin{tabular}{lllllllllll} 
Group & Sham & $15 \mathrm{~min}$ & $1 \mathrm{hr}$ & $4 \mathrm{hr}$ & $8 \mathrm{hr}$ & $1 \mathrm{~d}$ & $3 \mathrm{~d}$ & $7 \mathrm{~d}$ & $14 \mathrm{~d}$ & $28 \mathrm{~d}$ \\
\hline Immunohistochem & 4 & 4 & - & $6^{*}$ & 4 & 4 & $6^{*}$ & 4 & 4 & 2 \\
Western blot & 3 & 3 & - & 3 & 3 & 3 & 3 & 3 & - & - \\
EMSA & $10^{* *}$ & - & 5 & 5 & 5 & 5 & - & - & - & - \\
Imm-DB-label & 2 & - & - & 2 & 2 & - & - & - & - & -
\end{tabular}

*Including two rats per group for immuno-EM. **Including five sham-operated and five normal animals. Imm-DB-label, Immunofluorescence double-labeling studies.

\section{MATERIALS AND METHODS}

A total of 95 adult female Long-Evans rats (Simonsen Laboratory, Gilroy, CA), weighing 200-250 gm, were used in this study (Table 1). These included animals used for immunohistochemistry and immuno-EM studies $(n=38)$, Western blot analysis $(n=21)$, electrophoretic mobility shift assay (EMSA) $(n=30)$, and immunofluorescence double-labeling studies $(n=6)$.

Spinal cord injury. Impact injury was induced using a weight-drop device developed at New York University (Gruner, 1992) and followed a protocol developed by a multicenter consortium (Multicenter Animal Spinal Cord Injury Study; Basso et al., 1995, 1996a,b), which has been reported previously (Liu et al., 1997; Xu et al., 1998). Briefly, rats were anesthetized with pentobarbital $(50 \mathrm{mg} / \mathrm{kg}$, i.p.), and a laminectomy was performed at the T9-T10 level. After the spinous processes of T8 and T11 were clamped to stabilize the spine, the exposed dorsal surface of the cord was subjected to weight-drop impact using a $10 \mathrm{gm}$ rod $(2.5 \mathrm{~mm}$ in diameter) dropped at a height of $12.5 \mathrm{~mm}$. After the injury, the muscles and skin were closed in layers, and rats were placed in a temperature- and humidity-controlled chamber overnight. Manual bladder expression was performed at least three times daily until reflex bladder emptying was established. For the sham-operated controls, the animals underwent a T10 laminectomy without weight-drop injury. All surgical interventions and postoperative animal care were performed in accordance with the Guide for the Care and Use of Laboratory Animals (National Research Council, 1996) and the Guidelines and Policies for Rodent Survival Surgery provided by the Animal Care Committees of Washington University and St. Louis University.

Immunohistochemistry. Rats were killed at $15 \mathrm{~min}, 4 \mathrm{hr}, 8 \mathrm{hr}, 1 \mathrm{~d}, 3 \mathrm{~d}$, $7 \mathrm{~d}, 14 \mathrm{~d}$, and $28 \mathrm{~d}$ after injury, and sham-operated controls were killed at $4 \mathrm{hr}$ after a T10 laminectomy. Animals were deeply anesthetized with pentobarbital $(80 \mathrm{mg} / \mathrm{kg}$, i.p.) and perfused transcardially with $50 \mathrm{ml}$ of $0.9 \%$ saline, followed by $500 \mathrm{ml}$ of modified Zamboni fixative (Holets et al., 1987; Xu et al., 1995). After perfusion, the spinal cord was carefully dissected out, and a $14 \mathrm{~mm}$ segment containing the injury epicenter was blocked and post-fixed for an additional $2 \mathrm{hr}$ in the same fixative. The specimens were transferred to a solution containing $30 \%$ sucrose in $0.1 \mathrm{M}$ phosphate buffer (PB), pH 7.4, overnight. Each specimen was then blocked, from the epicenter of the injury in both rostral and caudal directions, into two segments: a segment $1-5 \mathrm{~mm}$ away from the injury epicenter for horizontal sections and a segment 5-7 mm away for transverse sections. Horizontal sections of the $1-5 \mathrm{~mm}$ segment were used to detect the proximodistal extent of GR immunoreactivity (IR), whereas the transverse sections through the $5-7 \mathrm{~mm}$ segment were used to visualize the laminar distribution of the labeling at varying time points. All sections were cut at $40 \mu \mathrm{m}$ on a cryostat, and the free-floating sections were processed for GR-IR using avidin-biotin-peroxidase complex (ABC) method. Briefly, sections were incubated with monoclonal mouse anti-GR antibody (1:400; Affinity Bioreagents Inc., Golden, CO) containing $0.3 \%$ Triton $\mathrm{X}-100$ and $1 \%$ normal goat serum for $24 \mathrm{hr}$ at $4^{\circ} \mathrm{C}$. After several rinses in $0.01 \mathrm{M}$ potassium PBS, the sections were reacted with biotinylated goat anti-mouse IgG (1:500; Vector Laboratories, Burlingame, CA) for $1 \mathrm{hr}$ and subsequently with Vector ABC (1:500; Vector) for $1 \mathrm{hr}$ at room temperature. The reaction product was revealed by incubation for 5 to 10 min with $0.02 \%$ diaminobenzidine tetrahydrochloride (DAB) and $0.003 \% \mathrm{H}_{2} \mathrm{O}_{2}$ in $0.05 \mathrm{M}$ Tris- $\mathrm{HCl}, \mathrm{pH}$ 7.6. After reactions, the sections were mounted on slides, dehydrated, cleared, and coverslipped. Slides were examined with an Olympus Optical (Tokyo, Japan) BX60 light microscope. In control sections, the primary antibody to GR was substituted by $1 \%$ normal mouse serum.

Western blotting. The Western blot analysis essentially followed the procedure described previously (Xu et al., 1998). Briefly, rats were given a lethal overdose of pentobarbital $(80 \mathrm{mg} / \mathrm{kg}$, i.p.) at various postopera- tive times and perfused intracardially with normal saline. A $10 \mathrm{~mm}$ cord segment containing the injury epicenter was taken and homogenized by sonication in a Western blot buffer, delipidated, and lyophilized. The pellets were dissolved in a $2 \%$ SDS solution. Twenty micrograms of protein from the supernatant of each sample was loaded onto a $8 \%$ polyacrylamide gel, separated by SDS-PAGE, and transferred to a nitrocellulose membrane by electrophoresis. The membrane was blocked in TBST (Tris buffered saline plus Tween 20) for $1 \mathrm{hr}$ at room temperature. Monoclonal mouse anti-GR primary antibody (1:400; Affinity Bioreagents Inc.) was added to the membrane and incubated at $4^{\circ} \mathrm{C}$ overnight. The membrane was washed three times with TBST for 10 min each and incubated with the secondary antibody, goat anti-mouse IgG, conjugated with alkaline phosphate $(1: 1000)$ at $4^{\circ} \mathrm{C}$ overnight. The membrane was then washed three times with TBST for $10 \mathrm{~min}$ each and two times with TBS (TBST without Tween 20). The color reaction for the Blot alkaline

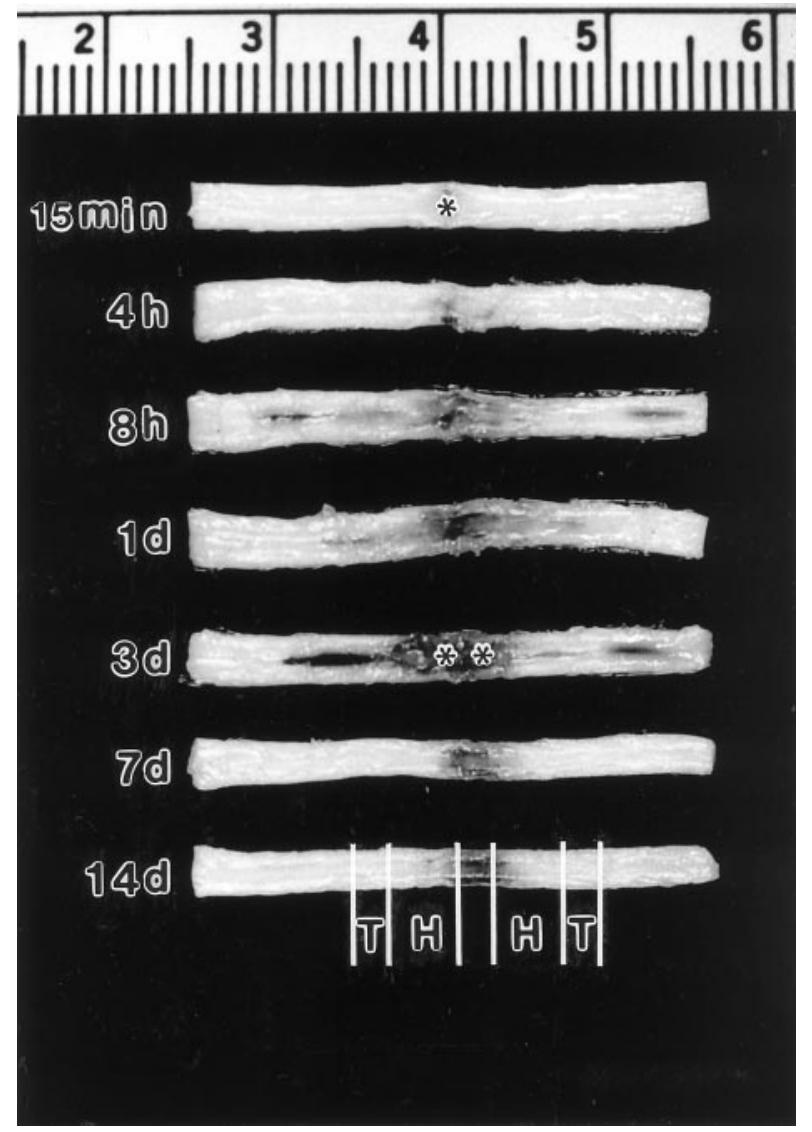

Figure 1. Gross appearance of the spinal cords in rats that received impact injury and were killed at varying post-injury time points. The epicenter of the injury can be detected as early as 15 min after injury (asterisk), and the necrosis associated with it progressed up to $3 \mathrm{~d}$ after injury (double asterisks). Reduction of the necrosis is observed at 7 and $14 \mathrm{~d}$ after injury. $H$, Segments $1-5 \mathrm{~mm}$ from the injury were taken for horizontal sections. $T$, Segments 5-7 mm from the injury were taken for transverse sections. 

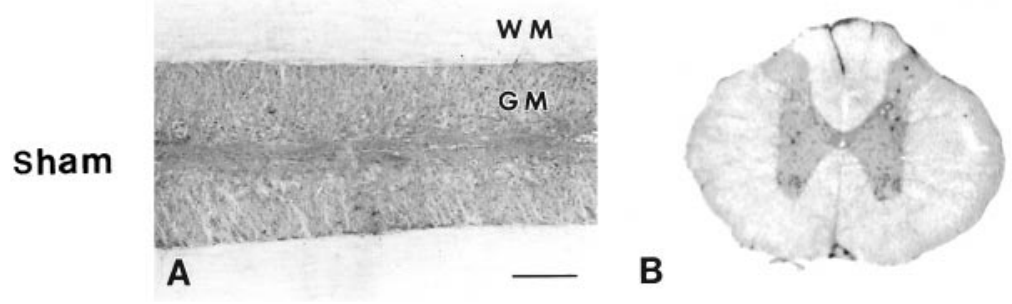

$15 \mathrm{~min}$
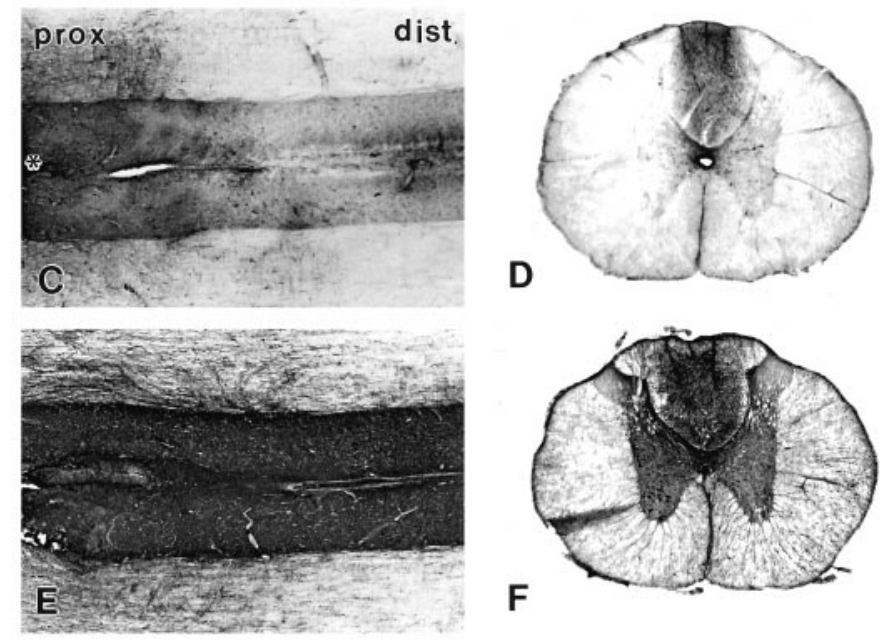

$1 d$

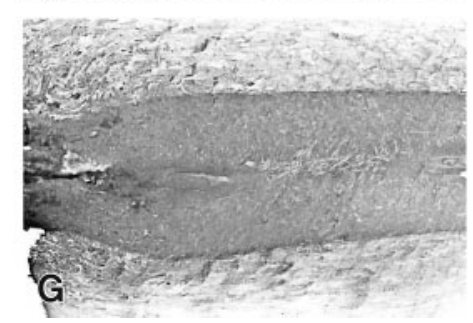

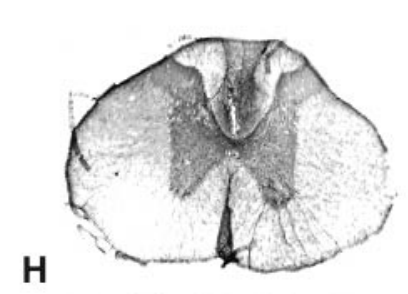

Figure 2. Time course of GR expression in the spinal cords of sham-operated or impacted rats. Left column, GR expression in horizontal sections of the spinal cord, $1-5 \mathrm{~mm}$ from the injury center. Areas proximal (prox.) or distal (dist.) to the injury are indicated in $C$. Right column, GR expression in transverse sections of the cord, 5-7 mm distal to the injury center. $A, B$, GR-IR was detectable at low levels in a sham-operated control. $C, D$, At 15 min after injury, there was a slight increase in GR-IR, mainly located in areas close to the lesion center (asterisks) and in the dorsal funiculus. $E, F$, GR expression was substantially increased at $4 \mathrm{hr}$ after injury, extending throughout the entire length of the specimen. $G, H$, At 1 d after injury, GR-IR sharply declined. Scale bar: $A-H, 500 \mu \mathrm{m}$. phosphatase system was conducted according to the technical manual provided by Promega (Madison, WI).

Preparation of nuclear extracts. Crude nuclear "mini-extracts" were prepared from sham-operated or injured spinal cord segments as described previously (An et al., 1993; Xu et al., 1998). Briefly, a 10-mm-long spinal cord segment containing the injury epicenter was removed, frozen immediately in liquid nitrogen, and stored at $-80^{\circ} \mathrm{C}$ until assay. For EMSA, frozen cord segments were homogenized in 3 vol of buffer A (10 $\mathrm{mm}$ HEPES, $1.5 \mathrm{~mm} \mathrm{MgCl}, 10 \mathrm{~mm} \mathrm{KCl}, 0.5 \mathrm{~mm}$ DTT, and $1 \mathrm{mg} / \mathrm{ml}$ leupeptin and aprotinin, $\mathrm{pH}$ 7.9) with a loose homogenizer and were placed on ice for $10 \mathrm{~min}$ and centrifuged at $3300 \times \mathrm{g}$ for $15 \mathrm{~min}$. The pellet was suspended in $3 \mathrm{ml}$ of buffer B (20 mM HEPES, $20 \mathrm{~mm} \mathrm{KCl}, 1.5$ $\mathrm{mM} \mathrm{MgCl}_{2}, 0.2 \mathrm{~mm}$ EDTA, $0.2 \mathrm{~mm}$ DTT, $0.2 \mathrm{~mm}$ PMSF, $1 \mathrm{mg} / \mathrm{ml}$ leupeptin and aprotinin, and $25 \%$ glycerol, $\mathrm{pH}$ 7.9). One milliliter of buffer C (20 mм HEPES, $1.2 \mathrm{M} \mathrm{KCl,} 0.2 \mathrm{~mm}$ EDTA, $0.5 \mathrm{~mm}$ DTT, $0.2 \mathrm{~mm}$ PMSF, and $1 \mathrm{mg} / \mathrm{ml}$ leupeptin and aprotinin, $\mathrm{pH}$ 7.9) was then added and mixed. The sample was placed on ice for $30 \mathrm{~min}$ and centrifuged at $15,000 \times g$ for $30 \mathrm{~min}$ at $4^{\circ} \mathrm{C}$. The supernatant was filtered and dialyzed against buffer D (20 mM HEPES, $100 \mathrm{~mm} \mathrm{KCl,} 0.2 \mathrm{~mm}$ PMSF, $0.5 \mathrm{~mm}$ DTT, and $20 \%$ glycerol, $\mathrm{pH} 7.9$ ) at $4^{\circ} \mathrm{C}$ overnight. The protein concentrations were determined by the Lowry method (Lowry et al., 1951).

Electrophoretic mobility shift assay. EMSA was applied to assess GRE binding activity. The following GRE consensus oligonucleotides (Tsai et al., 1988) were used: 5'-GATTCTGTACAGGATGTTCTAGCTACG3'; and 3'-GACATGTCCTACAAGATCGATGCTTAG-5'.

The GRE oligonucleotides were labeled with $\left[\gamma_{-}{ }^{32} \mathrm{P}\right] \mathrm{ATP}$ according to the Promega Technical Bulletin number 106 (Promega, Madison, WI). The binding reaction was described previously (An et al., 1993; Xu et al., 1998). The reaction was performed in a final volume of $20 \mu \mathrm{l}$ of solution containing binding buffer (10 mM Tris- $\mathrm{HCl}, 20 \mathrm{~mm} \mathrm{NaCl}, 1 \mathrm{~mm}$ DTT, 1 mM EDTA, and 5\% glycerol, at $\mathrm{pH} 7.6), 0.1 \mathrm{ng}$ of labeled probe $(>10,000$ $\mathrm{cpm}), 30 \mu \mathrm{g}$ of nuclear protein, and $1 \mu \mathrm{g}$ of poly $(\mathrm{dI} \cdot \mathrm{dC})$. After incubation for $20 \mathrm{~min}$ at room temperature, the mixture was subjected to electro- phoresis on a nondenaturing $6 \%$ polyacrylamide gel at $180 \mathrm{~V}$ for $2 \mathrm{hr}$ under a low ionic strength condition. The gel was dried and subjected to autoradiography.

Immunohistochemistry for electron microscopy. For immuno-EM, rats were perfused with the same perfusion fixatives as described above for immunohistochemistry but with the addition of $0.1 \%$ glutaraldehyde in the fixatives. After perfusion, the spinal cord was carefully dissected out and blocked into a proximal segment $(1-5 \mathrm{~mm}$ away from the injury epicenter) and a distal segment (5-7 $\mathrm{mm}$ away from the epicenter) in both rostral and caudal directions. Horizontal sections of the proximal segment and transverse sections of the distal segment were cut at $50 \mu \mathrm{m}$ on a vibratome. The sections were subjected to immunohistochemical processing for GR according to the method described above for light microscopy with modifications. Specifically, $0.01 \%$ instead of $0.3 \%$ Triton $\mathrm{X}-100$ was used in the blocking-incubation solution for immuno-EM. After DAB reaction, the sections were post-fixed in $1 \%$ osmium tetroxide in $0.1 \mathrm{M} \mathrm{PB}, \mathrm{pH} 7.4$, for $50 \mathrm{~min}$ at room temperature and dehydrated in graded ethanol and propylene oxide. During dehydration, uranyl acetate (7\%) was added to $70 \%$ ethanol $(30 \mathrm{~min})$ to improve tissue contrast. The sections were then flat-embedded in Epon on slides. After curing, sections were examined, and areas of interests were cut out and glued to Epon cylinders for ultrathin sectioning. The ultrathin sections were mounted on grids, counterstained with lead citrate, examined, and photographed using a Zeiss 109 electron microscope (Zeiss, Thornwood, NY).

Immunofluorescence double labeling for confocal microscopy. The immunofluorescence double-labeling method has been described in previous publications (Xu et al., 1995, 1997). Briefly, spinal cord segments from sham-operated or injured animals were embedded in tissue freezing medium, cut horizontally at $12 \mu \mathrm{m}$ on a cryostat, and mounted on gelatin-coated slides. Before primary antibody incubation, the sections were permeabilized and blocked with $0.3 \%$ Triton X-100-10\% normal goat serum in 0.01 M PBS for 15 min. Monoclonal mouse anti-GR (1:100; Affinity Bioreagents Inc.) and polyclonal rabbit anti-TNF- $\alpha$ antibodies 

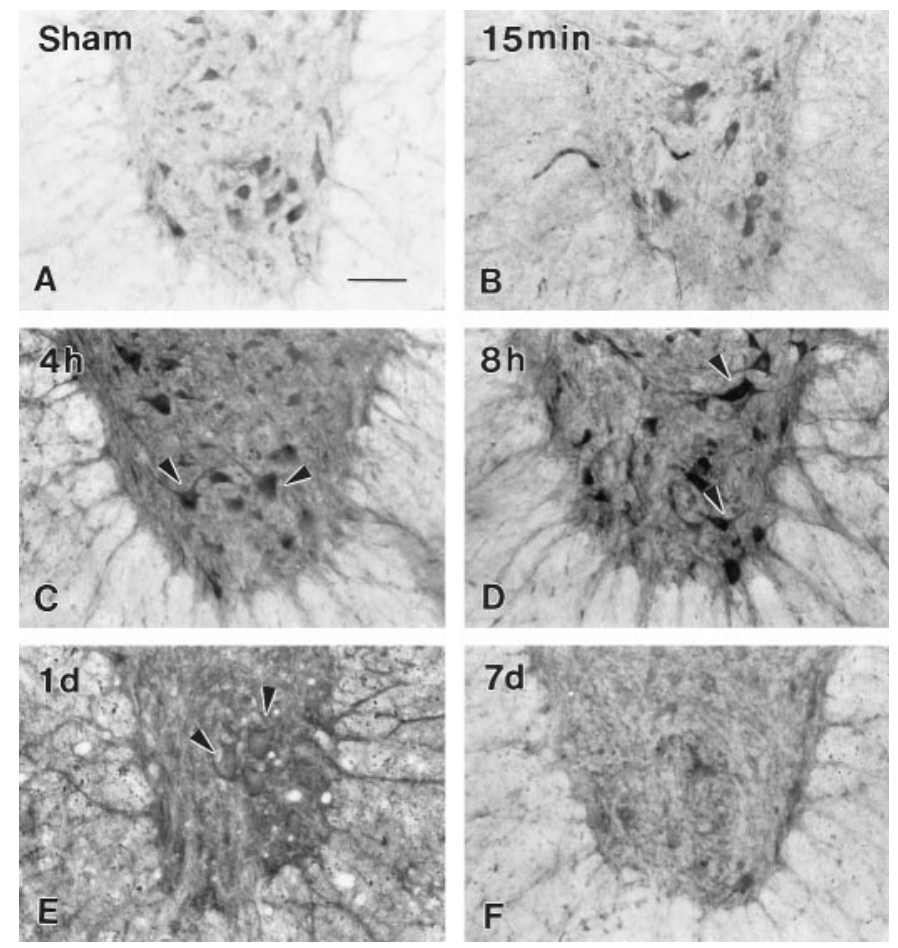

Figure 3. Expression of GR in the ventral horn of the spinal cord, 5-7 $\mathrm{mm}$ distal to the center of injury, in a sham-operated rat that received only laminectomy $(A)$ and in rats that received SCI and were killed at various postinjury time points $(B-F)$. $A$, A transverse section of the spinal cord in a sham-operated control showing a low level of GR-IR in ventral horn neurons. $B$, At $15 \mathrm{~min}$ after injury, GR expression increased slightly. $C, D$, The number of GR-IR neurons and their intensity of staining (arrowheads) increased substantially at $4(C)$ and $8(D)$ hr after injury. $E$, At $1 \mathrm{~d}$ after injury, cytoplasmic GR-IR (arrowheads) in ventral horn neurons decreased. $F$, At $7 \mathrm{~d}$ after injury, GR-IR returned almost to the baseline level. Scale bar: $A-F, 100 \mu \mathrm{m}$.

(1:100; Biosource, Camarillo, CA) were applied to the sections overnight at $4^{\circ} \mathrm{C}$. On the following day, the sections were incubated with fluorescein-conjugated goat anti-rabbit (1:100; ICN Biochemicals, Aurora, $\mathrm{OH})$ and rhodamine-conjugated rabbit anti-mouse $(1: 100$; ICN Biochemicals) antibodies. Slides were washed, mounted, and examined with an Olympus Optical Fluoview confocal microscope.

\section{RESULTS}

Spinal cord injury produced progressive degeneration at the site of injury (Fig. 1). The gross appearance of the injury epicenter was detected as early as 15 min after injury, and the destructive changes of the cord evolved up to $3 \mathrm{~d}$ after injury. Progression of tissue damage was not apparent at day 7 or later. These changes in gross appearance were similar to the histopathological changes of the cord reported previously (Liu et al., 1997).

\section{Temporal profile and spatial distribution of GR immunoreactivity after SCl}

In sham-operated controls, GR-IR was observed at low levels in both gray and white matters (Figs. 2, 3). At 15 min after injury, GR-IR was slightly increased in the gray matter surrounding the central canal and in the dorsal funiculus adjacent to the injury epicenter (Figs. 2, 3). At 4 hr after injury, strong GR expression extended from the injury center to rostral and caudal cord segments (Fig. 2). In fact, increased GR-IR was observed throughout the entire length of the cord specimen (14 $\mathrm{mm}$ in length). The labeling was stronger in the gray matter than in the white matter. In the gray matter, many neurons in the ventral horn and inter-
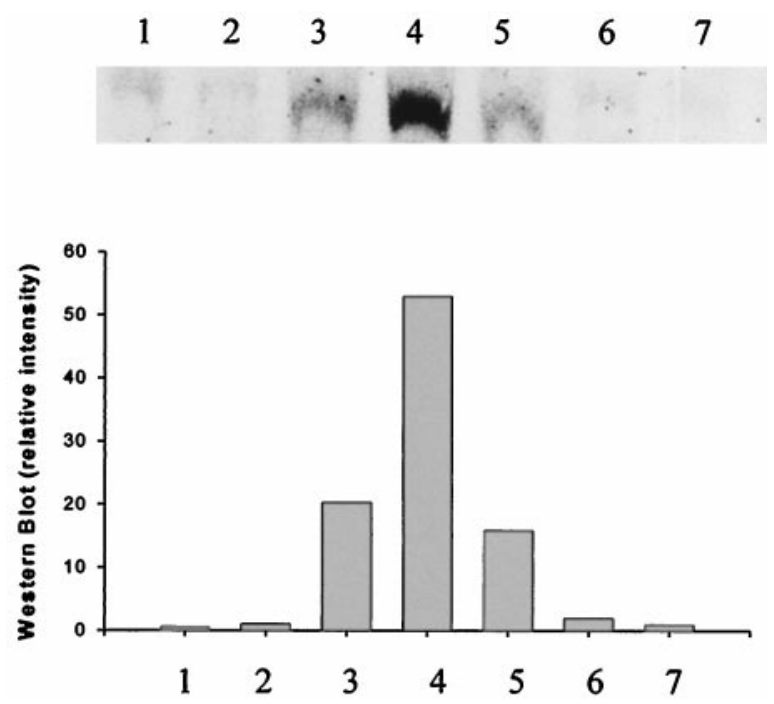

Figure 4. Western blot analysis quantifying GR protein expression at varying time points after SCI. Lane 1, GR standard; lane 2, 15 min; lane 3, $4 \mathrm{hr}$; lane 4, $8 \mathrm{hr}$; lane 5,1 d; lane 6, $3 \mathrm{~d}$; lane 7, $7 \mathrm{~d}$. The bottom depicts the compiled results obtained from three animals per time point.

mediate zone showed strong GR-IR (Figs. 2, 3). GR-IR reached its peak at $8 \mathrm{hr}$ after injury when intense labeling was observed throughout the entire length of the specimen (Fig. 3). At $1 \mathrm{~d}$ after injury, GR expression was rapidly declined and confined mainly to areas adjacent to the lesion site (Figs. 2, 3). GR-IR was reduced to near or below baseline level at 3 and $7 \mathrm{~d}$ after injury and remained at that level thereafter (Fig. 3). In control sections incubated with normal mouse $\mathrm{IgG}$ in the absence of the primary antibody for GR, there was no labeling (data not shown).

\section{Western blot analysis for GR after SCI}

To confirm the immunohistochemical detection of GR and to quantify its expression after SCI, Western blot analysis of GR was performed (Fig. 4). Consistent with immunohistochemistry, basal GR expression was detected as a band of light labeling with a molecular weight of $97 \mathrm{kDa}$ in sham-operated controls. At $15 \mathrm{~min}$ after injury, GR expression was almost identical to the baseline level, although a slight increase in GR-IR was detected in areas surrounding the lesion by immunohistochemistry. At $4 \mathrm{hr}$ after injury, GR-expression was increased 22-fold compared with the sham-operated controls based on densitometric analysis. By $8 \mathrm{hr}$ after injury, GR expression reached its peak, 56-fold higher than the sham-operated controls. The GR protein expression then declined at $1 \mathrm{~d}$ after injury and returned to the baseline level at 3 and $7 \mathrm{~d}$ (Fig. 4).

\section{Electrophoretic mobility shift assay for GRE binding activity after SCl}

GRE binding activity was determined by EMSA in samples taken from animals killed at 1, 4, 8, and $24 \mathrm{hr}$ after injury, as well as from non-operated normal and sham-operated controls (Fig. 5). A small amount of GRE binding activity was detected in normal and sham-operated rats. The GRE binding activity increased at 1 hr after injury, peaked at $4 \mathrm{hr}$, and declined at 8 and $24 \mathrm{hr}$ after injury.

Cellular and subcellular localization of GR-IR after SCI

Cellular and subcellular localization of GR-IR was performed using immunohistochemistry at light and electron microscopic 


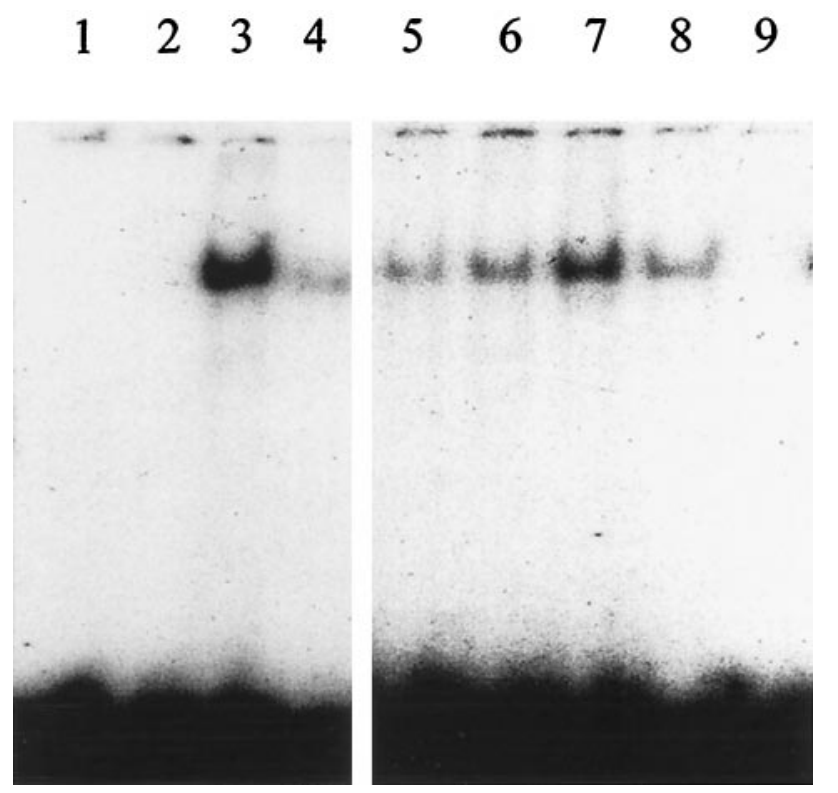

Figure 5. EMSA demonstrating GRE binding activity in normal, shamoperated controls, and SCI animals. Lane 1, Free probe; lane 2, $4 \mathrm{hr}$ after SCI plus $50 \times$ cold GRE probe; lane $3,4 \mathrm{hr}$ after SCI; lane 4, shamoperated control; lane 5, normal control; lane 6, $1 \mathrm{hr}$ after SCI; lane 7, 4 $\mathrm{hr}$ after SCI; lane 8, $8 \mathrm{hr}$ after SCI; lane 9, $1 \mathrm{~d}$ after SCI.

levels. At the light microscopic level, extensive GR-IR was observed throughout the entire neuropil of the gray matter at 4 and $8 \mathrm{hr}$ after injury (Fig. 6A). In cells with the morphological characteristics of neurons, GR-IR was detected not only in the cytoplasm but also the nucleus. In the adjacent white matter, GR-IR was noted in glial cells as well. These cells, with the morphological characteristics of oligodendrocytes, formed longitudinal rows in the white matter in the long axis of the spinal cord (Fig. 6B).

At the EM level, GR-IR was found in neurons, oligodendrocytes, and astrocytes (Fig. 7). Neurons containing GR-IR had oval or round cell somata. In addition, strong GR-IR was noted in dendrites. Interestingly, axons and their presynaptic terminals were not immunoreactive for GR. These GR-negative axon terminals containing small clear spherical vesicles made axodendritic synapses with GR-positive dendrites or axosomatic synapses with GR-positive somata (Fig. 7C). Some other cell types, such as endothelial cells, were found to be GR-negative (Fig. 7A).

\section{Immunofluorescence colocalization of GR and TNF- $\alpha$ after $\mathbf{S C I}$}

TNF- $\alpha$ is a key proinflammatory cytokine that is expressed after SCI (Yakovlev and Faden, 1994; Wang et al., 1996; Bartholdi and Schwab, 1997; Xu et al., 1998). We have shown previously profound suppression of post-traumatic TNF- $\alpha$ expression by MP (Xu et al., 1998). To study whether GR and TNF- $\alpha$ were expressed in the same cells, we performed immunofluorescence double-labeling experiments in animals killed at 4 and $8 \mathrm{hr}$ after injury and in sham-operated controls. The labeling was examined using Olympus Optical Fluoview confocal microscopy, and the cell type was determined by morphological and size characteristics (Fig. 8). In the spinal cord gray matter of injured rats, expression of TNF- $\alpha$ and GR could be localized to the same neurons (Fig. 8A-C, arrows). However, cells expressing either TNF- $\alpha$ or GR were also found (Fig. $8 A-C$, double arrowheads). In
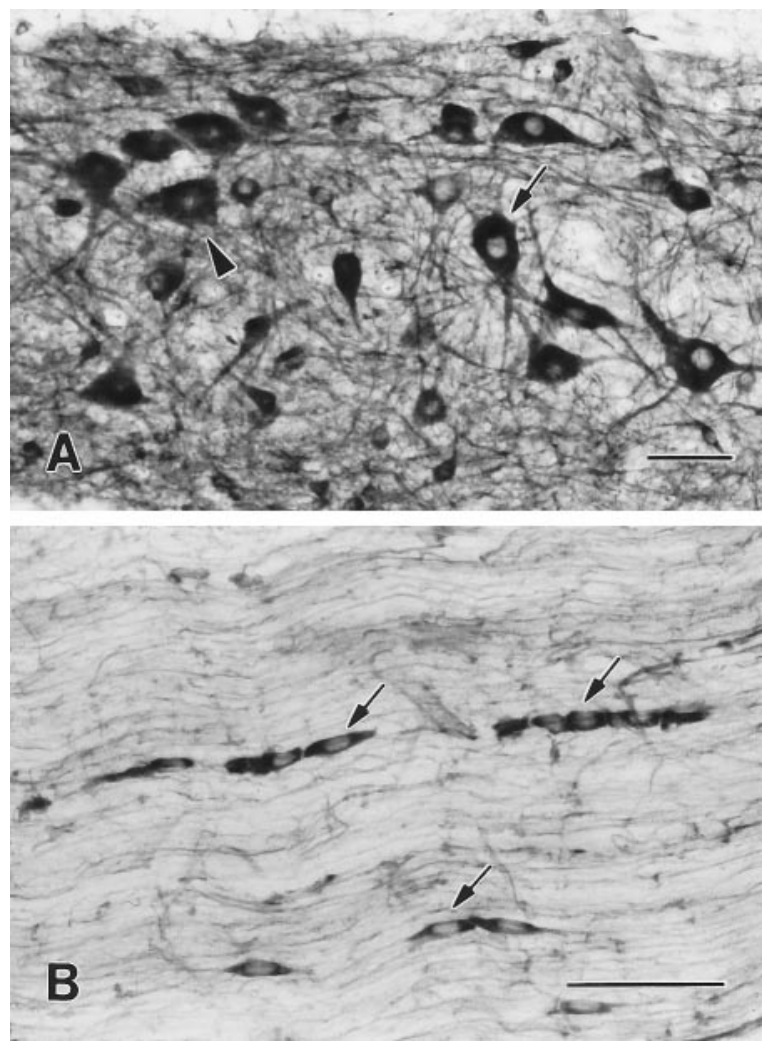

Figure 6. Expression of GR in the gray and white matter of the spinal cord at $4 \mathrm{hr}$ after injury. $A$, A horizontal section of the spinal cord showing extensive GR-IR in the gray matter. The area was taken at $\sim 2$ $\mathrm{mm}$ distal to the injury center. Note that GR-IR is present in the cytoplasm alone (arrow) or in both the cytoplasm and nucleus (arrowhead) of cells morphologically similar to neurons. In the latter case, only the nucleoli are unstained. $B$, In the adjacent white matter, a row of GR-IR cells, morphologically similar to oligodendrocytes, are seen (arrows). Scale bars: $A, B, 50 \mu \mathrm{m}$.

the white matter, colocalization of TNF- $\alpha$ and GR was observed in cells morphologically suggestive of oligodendrocytes (Fig. $8 D-F$, arrows). In most instances, these cells were in close apposition with TNF- $\alpha$-positive axons. Axons, although positive for TNF- $\alpha$, were GR-negative (Fig. 8D-F, double arrowheads). In control animals, low levels of GR but not TNF- $\alpha$ were detected (results not shown). In sections incubated with normal mouse or rabbit IgG, neither GR-IR nor TNF- $\alpha$-IR was observed (results not shown).

\section{DISCUSSION}

In the present study, temporal and spatial patterns of GR expression and its subcellular localization were investigated after SCI in adult rats. We demonstrated that GR expression was slightly increased at $15 \mathrm{~min}$ after injury, rapidly increased at $4 \mathrm{hr}$, peaked at $8 \mathrm{hr}$, sharply declined at $1 \mathrm{~d}$, returned to the baseline level at $3 \mathrm{~d}$, and remained at that level thereafter. Spatially, GR-IR was initially observed at the impact site and progressively spread to the distant areas. Nuclear proteins isolated from the injured cord showed an increase in binding activity to GRE, demonstrating a functional element of GR activation. During peak expression, GR-IR was found in neuronal somata and dendrites but not in axons and terminals. GR-IR was also found in oligodendrocytes and astrocytes. Colocalization of GR and TNF- $\alpha$ was observed in cells morphologically, suggestive of neurons and oligodendro- 
Figure 7. Immuno-EM demonstrating cellular and subcellular distribution of GR at $4 \mathrm{hr}$ after injury. GR-IR was observed in neurons $(N e ; A)$, astrocytes $(A s ; A)$, and oligodendrocytes $(\mathrm{Oli} ; B)$. All asterisks indicate sites of GR expression. A postsynaptic element of a synapse is shown positive for GR ( $A$, arrow), whereas its presynaptic component was negative. Such synapses, more clearly seen in $C$ (arrows), were distributed widely in the gray matter of the spinal cord during the period of increased expression of GR. The endothelium of blood vessels $(B V ; A)$ were not immunoreactive to GR. Scale bars: $A-C, 1 \mu \mathrm{m}$.
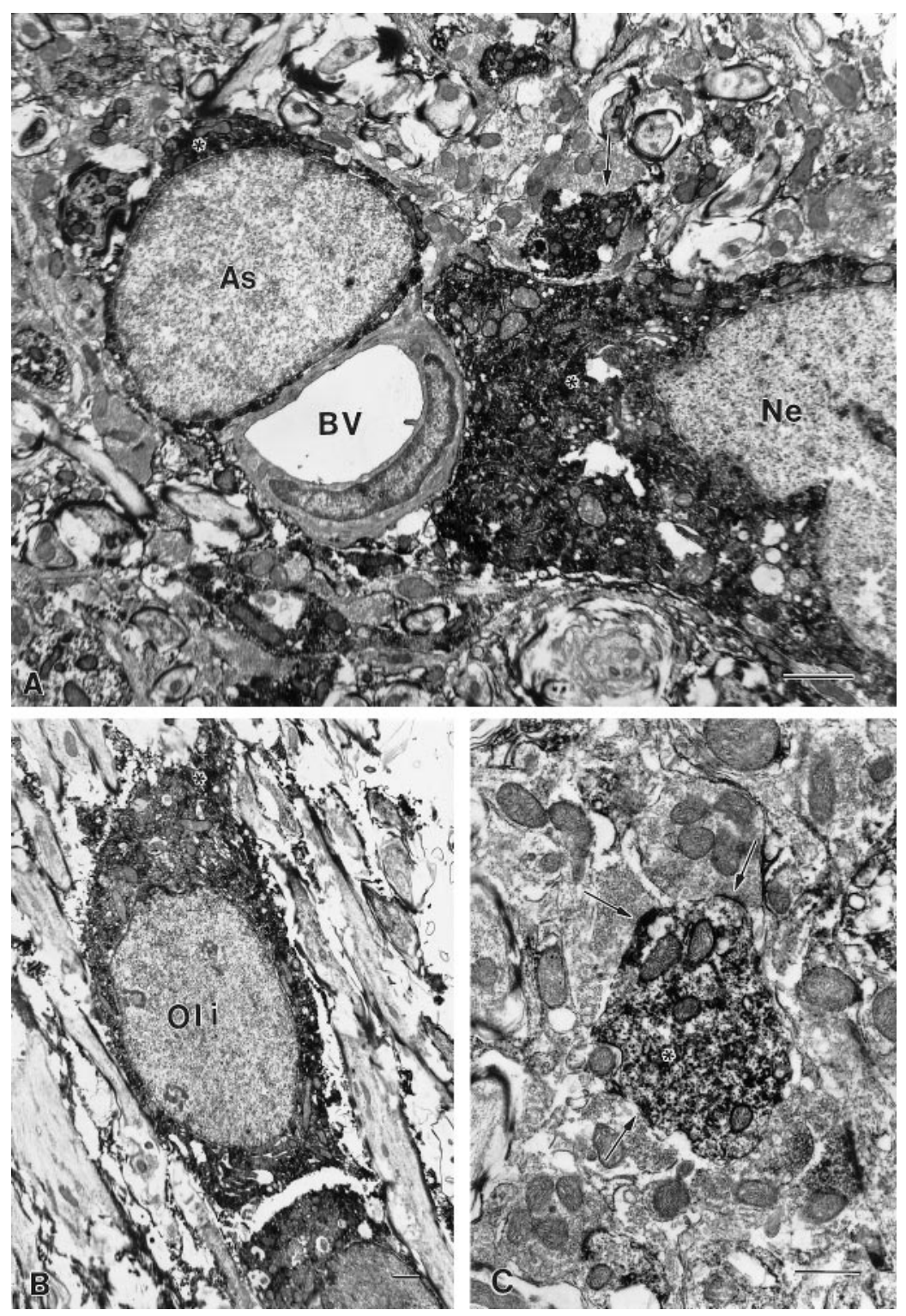

cytes. Thus, our study demonstrates that GR intensely expressed within the first $8 \mathrm{hr}$ of SCI. To our knowledge, this is the first study to document an increase in GR expression after an acute SCI in animals.

\section{Post-traumatic inflammation and anti-inflammation function of MP}

Post-traumatic inflammation has been implicated in the secondary injury process after SCI (Hsu and Dimitrijevic, 1990; Bartholdi and Schwab, 1995, 1997). TNF- $\alpha$ is a key inflammatory mediator that is expressed after SCI (Yakovlev and Faden, 1994; Wang et al., 1996; Bartholdi and Schwab, 1997). We have confirmed recently an increase in TNF- $\alpha$ expression after SCI (Xu et al., 1998). In addition, the receptors for both $\mathrm{p} 55$ and $\mathrm{p} 75$ subunits of TNF- $\alpha$ were substantially increased (Li et al., 1998). We further demonstrated that the expression of TNF- $\alpha$ was accompanied by an increase in NF- $\kappa \mathrm{B}$ binding activity in nuclear proteins isolated from the injury cord (Xu et al., 1998). Most significantly, high doses of MP considerably reduced TNF- $\alpha$ expression and $\mathrm{NF}-\kappa \mathrm{B}$ binding activity ( $\mathrm{Xu}$ et al., 1998). These findings, along with the findings by others (Yakovlev and Faden,
1994; Bartholdi and Schwab, 1995, 1997; Wang et al., 1996; Bethea et al., 1998), suggest that post-traumatic inflammation may involve TNF- $\alpha$ and NF- $\kappa \mathrm{B}$, which can be suppressed by MP. Although the antioxidant effect of MP, which is independent from GR-mediated actions (Anderson et al., 1988, Behrman et al., 1994), has been emphasized, the anti-inflammatory effect of MP has also been raised (Hsu and Dimitrijevic, 1990; Bartholdi and Schwab, 1995). Colocalization of GR and TNF- $\alpha$ in the same neurons and glial cells in the present study is consistent with an effect of MP in suppressing post-traumatic TNF- $\alpha$ expression after SCI (Xu et al., 1998).

\section{Possible actions of GR in mediating traumatic SCI}

The present study shows a significant increase in GR expression after SCI. The pathophysiological relevance of the elevated levels of GR in the traumatically injured spinal cord remains to be determined. In the CNS of normal adult rats, a widespread distribution of GR-IR has been demonstrated (Fuxe et al., 1985; Ahima and Harlan, 1990). The GR, an intracellular receptor, was found in the cytoplasm and nucleus of neurons and glial cells. It has been suggested that the biological effects of glucocorticoids 

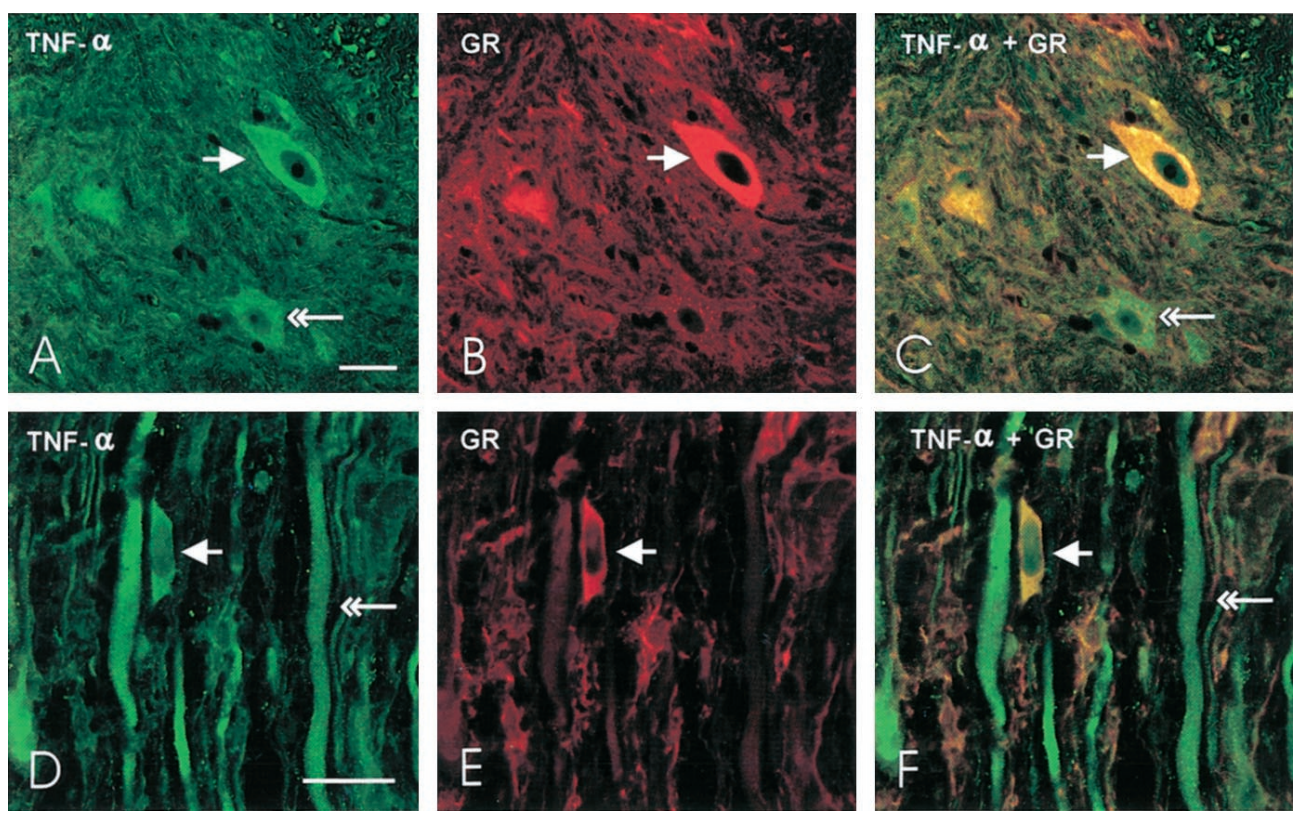

Figure 8. Immunofluorescence confocal imaging showing colocalization of GR and TNF- $\alpha$ at 4 hr after injury. $A-C$, A morphologically identified neuron in the ventral horn was positive for TNF- $\alpha(A$, arrow), as well as for GR (B, arrow). Coexistence of TNF- $\alpha$ and GR in the same cell $(C$, arrow). Note that a cell expressing TNF- $\alpha$ alone (double arrowheads, $A$ and $C$ ), but not GR, is also shown. $D-F$, In a longitudinal section of the white matter, an oligodendrocyte-like cell (arrow) was positive for TNF- $\alpha$ and was in close association with a TNF- $\alpha$-positive axon. The same cell was also positive for GR (E, arrow). Coexistence of TNF- $\alpha$ and GR in the same cell is shown $(F$, arrow). Notice that axons, positive for TNF- $\alpha$ (double arrowheads), were GR-negative. Scale bars: $A-F, 10 \mu \mathrm{m}$.

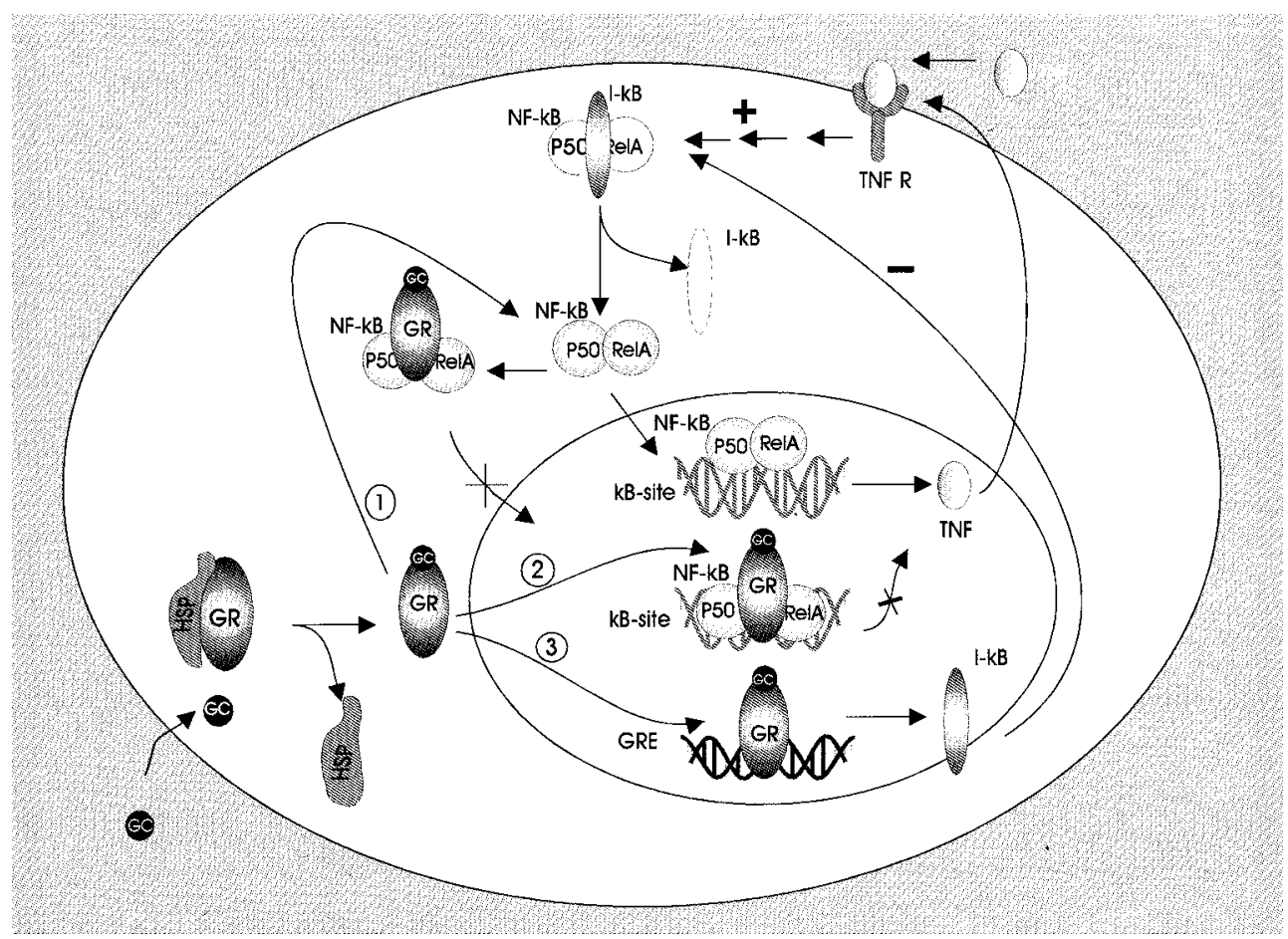

Figure 9. Possible actions of GR after acute SCI. We suggest the effect of TNF- $\alpha$ is mediated through its receptor TNF-R and, in turn, the activation of a proinflammatory transcription factor NF- $\kappa$ B. The activated glucocorticoid receptor complex may protect the spinal cord from secondary injury through three potential mechanisms: (1) binds to and inactivates key proinflammation transcription factor, NF- $\kappa \mathrm{B}$, through protein-protein interaction in the cytoplasm, (2) binds to and inactivates NF- $\kappa \mathrm{B}$ in the nucleus, and (3) upregulates the expression of cytokine inhibitory protein I $\kappa \mathrm{B}$ through GRE to inactivate NF- $\kappa \mathrm{B}$ thereby inhibiting the secondary expression of a series of inflammatory cytokines. $G C$, Glucocorticoids; $G R$, glucocorticoid receptor; $G R E$, glucocorticoid responsive elements; $H s p$, heat shock protein; $N F-\kappa B$, transcription factor nuclear factor $\kappa \mathrm{B} ; p 50, R e l A$, subunits of NF- $\kappa \mathrm{B}$; $I \kappa B$, an inhibitory molecule, $\kappa B$-site, DNA sequence for NF- $\kappa \mathrm{B}$ binding; $T N F-\alpha$, tumor necrosis factor- $\alpha$; TNF-R, tumor necrosis factor receptor. 
are mediated by GR, which transduces the hormonal signal to the nucleus and participates directly in gene regulation (Yamamoto, 1985). In the absence of the hormone, the receptor appears to be localized predominantly in the cytoplasm complexed with other proteins (Vedeckis, 1983; Mendel et al., 1986; Sanchez et al., 1987). Upon binding steroid, this complex dissociates, and the receptor enters the nucleus, dimerizes, and binds to a specific DNA sequence, the GRE, which is upstream of glucocorticoid response genes (Tsai et al., 1988). In the present study, increased GR-IR was found in both the cytoplasm and nucleus of affected cells after SCI. Furthermore, the nuclear protein binding activity to GRE based on EMSA was significantly increased after injury. These results suggest that, after SCI, GR expression is followed by translocation and transcription activity involving GRE. The subsequent nuclear events after GR expression remain to be fully delineated.

Glucocorticoids, specifically the MP, may confer antiinflammation function through several different pathways (summarized in Fig. 9). First, the activated glucocorticoid-receptor complex may bind to and inactivate key proinflammatory transcription factors such as NF- $\kappa$ B. Such effects may be a result of direct protein-protein interaction (GR-NF- $\kappa \mathrm{B}$ interaction) or may take place at the promotor responsive element level (for review, see Cato and Wade, 1997). Second, the protective effect of MP may also be mediated via GRE, which upregulates $\mathrm{I} \kappa \mathrm{B}$, the cytoplasmic inhibitor of NF- $\kappa \mathrm{B}$ (Auphan et al., 1995). I $\kappa \mathrm{B}$ and $\mathrm{NF}-\kappa \mathrm{B}$ form a complex, preventing the nuclear translocation of the latter and thereby inhibiting the secondary expression of a series of inflammatory cytokines.

\section{Cellular and subcellular localization of GR}

Glucocorticoids have been suggested to regulate many molecules in various cells in the CNS. For example, corticosterone, a glucocorticoid, regulates GFAP expression in astrocytes in the spinal cord of Wobbler mice (De Nicola, 1998), which may provide a clue for its regulation on the formation of gliosis after SCI. In addition, oligodendrocytes and microglia may also be glucocorticoid-sensitive. The localization of GR in neurons and glial cells in the injured spinal cord suggests that GR could possibly protect these cells from secondary degeneration if a GR ligand, such as MP, is presented in a timely manner. It is interesting that endothelial cells do not express GR. The distribution of GR is also compartment-specific. In neurons, only cell bodies and dendrites express GR, whereas the axons and terminals do not. The heterogeneous distributions of GR after SCI may be directly related to the function of each cell type. It should be emphasized that cells at a considerable distance from the site of injury also express GR, indicating that GR may influence cell functions distant from the injury.

\section{Possible mechanisms of regulation of GR expression after SCI}

Several possible mechanisms may be considered to explain the increased expression of GR after SCI. First, inflammatory cytokines may induce the production of endogenous glucocorticoids, which in turn stimulates and maintains GR expression. It has been shown that cytokines, such as TNF- $\alpha$, interleukin-1 $\beta$ (IL$1 \beta)$, and IL-6, were induced systemically and locally after SCI (Yakovlev and Faden 1994, Wang et al., 1996, 1997; Bartholdi and Schwab 1997; Xu et al., 1998). IL-1 $\beta$ and IL-6 may enhance glucocorticoid production via elevating corticotropin-releasing hormone and/or adrenocorticotropin hormone levels (Hermus and Sweep, 1990). It has been suggested that glucocorticoids are important in activating GR and maintaining the immunoreactivity of GR (Visser et al., 1996). Second, inflammatory cytokines may stimulate GR expression directly. For example, TNF- $\alpha$ has been shown to increase GR expression and enhance glucocorticoid-induced transcriptional activity of GR in vitro (Costas et al., 1996, 1997). The colocalization of GR and TNF- $\alpha$ in neurons and glial cells observed in this study suggests that TNF- $\alpha$ may play a role in regulating GR expression and vice versa. Last, neurotransmitters may influence the activation of GR. For example, GR levels in the intermediate lobe of the pituitary can be regulated by dopamine activity (Antakly et al., 1987). In the present study, GR-IR was found in neuronal somata and dendrites that form postsynaptic elements for axosomatic and axodendritic synapses. Interestingly, the presynaptic elements, i.e., axonal terminals, were GR-negative. These presynaptic terminals contain clear vesicles with putatively different neurotransmitters. This fine structural observation between GR-negative presynaptic and GR-positive postsynaptic elements raises the possibility that GR expression in neurons may be regulated in part by neurotransmitters at the site of junction.

\section{REFERENCES}

Ahima RS, Harlan RE (1990) Charting of type II glucocorticoid receptor-like immunoreactivity in the rat central nervous system. Neuroscience 39:579-604.

An G, Lin TN, Liu JS, Xue JJ, He YY, Hsu CY (1993) Expression of $c$-fos and $c$-jun family genes after focal cerebral ischemia. Ann Neurol 33:457-464.

Anderson DK, Saunders RD, Demediuk P, Dugan LL, Braughler JM, Hall ED, Means ED, Horrocks LA (1985) Lipid hydrolysis and peroxidation in injured spinal cord: partial protection with methylprednisolone or vitamin E and selenium. Cent Nerv Syst Trauma 2:257-267.

Anderson DK, Braughler JM, Hall ED, Waters TR, McCall JM, Means ED (1988) Effects of treatment with U-74006F on neurological outcome following experimental spinal cord injury. J Neurosurg 69:562-567.

Antakly T, Mercille S, Cote JP (1987) Tissue-specific dopaminergic regulation of the glucocorticoid receptor in the rat pituitary. Endocrinology 120:1558-1562.

Auphan N, DiDonato JA, Rosette C, Helmberg A, Karin M (1995) Immunosuppression by glucocorticoids: inhibition of NF- $\kappa \mathrm{B}$ activity through induction of I- $\kappa$ B synthesis. Science 270:286-290.

Bartholdi D, Schwab ME (1995) Methylpredisolone inhibits early inflammatory processes but not ischemic cell death after experimental spinal cord lesion in the rat. Brain Res 672:177-186.

Bartholdi D, Schwab ME (1997) Expression of pro-inflammatory cytokine and chemokine mRNA upon experimental spinal cord injury in mouse: an in situ hybridization study. Eur J Neurosci 9:1422-1438.

Basso DM, Beattie MS, Bresnahan JC (1995) A sensitive and reliable locomotor rating scale for open field testing in rats. J Neurotrauma $12: 1-21$.

Basso DM, Beattie MS, Bresnahan JC (1996a) Graded histological and locomotor outcomes after spinal cord contusion using the NYU weightdrop device versus transection. Exp Neurol 139:244-256.

Basso DM, Beattie MS, Bresnahan JC, Anderson DK, Faden AI, Gruner JA, Holfod TR, Hsu CY, Noble LJ, Nockels R, Perot PL, Salzman SK, Young W (1996b) MASCIS evaluation of open field locomotor scores: effects of experience and teamwork on reliability. Multicenter animal spinal cord injury study. J Neurotrauma 13:343-359.

Behrmann DL, Bresnahan JC, Beattie MS (1994) Modeling of acute spinal cord injury in the rat: neuroprotection and enhanced recovery with methylprednisolone, U-74006F and YM-14673. Exp Neurol 126:61-75.

Bethea JR, Castro M, Keane RW, Lee TT, Dietrich WD, Yezierski RP (1998) Traumatic spinal cord injury induces NF- $\kappa$ B activation. J Neurosci 18:3251-3260.

Bracken MB, Holford TR (1993) Effect of timing of methylprednisolone or naloxone administration on recovery of segmental and long-tract neurological function in NASCIS 2. J Neurosurg 79:500-507. 
Bracken MB, Freeman Jr DH, Hellenbrand K (1981) Incidence of acute traumatic hospitalized spinal cord injury in the United States, 19701977. Am J Epidemiol 113:615-622.

Bracken MB, Shepard MJ, Collins WF, Holford TR, Young W, Baskin DS, Eisenberg HM, Flamm E, Leo-Summers L, Maroon J, Marshall LF, Perot Jr PL, Piepmeier J, Sonntag VKH, Wagner FC, Wilberger JE, Winn HR (1990) A randomized, controlled trial of methylprednisolone or naloxone in the treatment of acute spinal cord injury: results of the Second National Acute Spinal Cord Injury Study. N Engl J Med 322:1405-1411.

Bracken MB, Shepard MJ, Collins Jr WF, Holford TR, Baskin DS, Eisenberg HM, Flamm E, Leo-Summers L, Maroon J, Marshall LF, Perot Jr PL, Piepmeier J, Sonntag VKH, Wagner FC, Wilberger JE, Winn HR, Young W (1992) Methyprednisolone or naloxone treatment after acute spinal cord injury: 1 year follow-up data: results of the Second National Acute Spinal Cord Injury Study. J Neurosurg 76:23-31.

Bracken MB, Shepard MJ, Holford TR, Leo-Summers L, Aldrich EF, Fazl M, Fehlings MG, Herr DL, Hitchon PW, Marshall LF, Nockels RP, Pascale V, Perot Jr PL, Piepmeier J, Sonntag VKH, Wagner FC, Wilberger JE, Winn HR, Young W (1997) Administration of methylprednisolone for 24 or $48 \mathrm{hr}$ or tirilazad mesylate for $48 \mathrm{hr}$ in the treatment of acute spinal cord injury. Results of the Third National Acute Spinal Cord Injury Randomized Controlled Trial. National Acute Spinal Cord Injury Study. JAMA 277:1597-1604.

Braughler JM, Hall ED (1982) Correlation of methylprednisolone levels in cat spinal cord with its effects on $\left(\mathrm{Na}^{+}+\mathrm{K}^{+}\right)$-ATPase, lipid peroxidation and alpha motor neuron function. J Neurosurg $56: 838-844$

Cato AC, Wade E (1996) Molecular mechanisms of anti-inflammatory action of glucocorticoids. BioEssays 18:371-378.

Costas M, Trapp T, Pereda MP, Sauer J, Rupprecht R, Nahmod VE, Reul JM, Holsboer F, Arzt E (1996) Molecular and functional evidence for in vitro cytokine enhancement of human and murine target cell sensitivity to glucocorticoids. TNF-alpha priming increases glucocorticoid inhibition of TNF-alpha-induced cytotoxicity/apoptosis. J Clin Invest 98:1409-1416.

Costas M, Kovalovsky D, Arzt E (1997) Mechanisms of glucocorticoid sensitivity modulation by cytokines. Medicina $57: 75-80$.

Demopoulos HB, Flamm ES, Seligman ML, Pietronigro DD, Tomasula J, DeCrescito V (1982) Further studies on free-radical pathology in the major central nervous system disorders: effects of very high doses of methylprednisolone on the functional outcome, morphology, and chemistry of experimental spinal cord inpact injury. Can J Physiol Pharmacol 60:1415-1424.

De Nicola AF, Ferrini M, Gonzalez SL, Gonzalez Deniselle MC, Grillo CA, Piroli G, Saravia F, de Kloet ER (1998) Regulation of gene expression by corticoid hormones in the brain and spinal cord. J Steroid Biochem Mol Biol 65:253-272.

Dhib-Jalbut SS, Xia Q, Drew PD, Swoveland PT (1995) Differential up-regulation of HLA class I molecules on neuronal and glial cell lines by virus infection correlates with differential induction of IFN-beta. J Immunol 155:2096-2108.

Fuxe K, Harfstrand A, Agnati LF, Yu ZY, Cintra A, Wikstrom AC, Okret S, Cantoni E, Gustafsson JA (1985) Immunocytochemical studies on the localization of glucocorticoid receptor immunoreactive nerve cells in the lower brain stem and spinal cord of the male rat using a monoclonal antibody against rat liver glucocorticoid receptor. Neurosci Lett 60:1-6.

Gruner JA (1992) A monitored contusion model of spinal cord injury in the rat. J Neurotrama 9:123-128.

Hall AV, Antoniou H, Wang Y, Cheung AH, Arbus AM, Olson SL, Lu WC, Kau C-L, Marsden PA (1994) Structural organization of the human neuronal nitric oxide synthase gene (NOS1). J Biol Chem 269:33082-33090.

Hall ED (1992) The neuroprotective pharmacology of methylprednisolone. J Neurosurg 76:13-22.

Hall ED, Braughler JM (1981) Acute effects of intravenous glucocorticoid pretreatment on the in vitro peroxidation of cat spinal cord tissue. Exp Neurol 73:321-324.

Hall ED, Braughler JM (1982) Effects of intravenous methylprednisolone on spinal cord lipid peroxidation and $\left(\mathrm{Na}^{+}+\mathrm{K}^{+}\right)$-ATPase activity. Dose-response analysis during 1st hour after contusion injury in the cat. J Neurosurg 57:247-253.
Hermus AR, Sweep CG (1990) Cytokines and the hypothalamic-pituitary-adrenal axis. J Steroid Biochem Mol Biol 37:867-871.

Holets VR, Hökfelt T, Ude J, Eckert M, Penzlin H, Verhofstad AA, Visser TJ (1987) A comparative study of the immunohistochemical localization of a presumptive proctolin-like peptide, thyrotropin releasing hormone and 5-hydroxytryptamine in the rat central nervous system. Brain Res 408:141-153.

Hsu CY, Dimitrijevic MR (1990) Methylprednisolone in spinal cord injury: the possible mechanism of action. J Neurotrauma 7:115-119.

Li Q, Yan P, Hsu CY, Xu J, He Y, Xu XM (1998) Expression of tumor necrosis factor receptor and nuclear factor kappa B in adult rats following traumatic spinal cord injury. Soc Neurosci Abstr 24:738.

Liu XZ, Xu XM, Hu R, Du C, Zhang SX, McDonald JW, Dong HX, Wu YJ, Fan GS, Jacquin MF, Hsu CY, Choi DW (1997) Neuronal and glial apoptosis after traumatic spinal cord injury. J Neurosci 17:5395-5406.

Lowry OH, Rosebrough NJ, Farr AL, Randal RJ (1951) Protein measurement with the Folin phenol reagent. J Biol Chem 193:265-275.

Means ED, Anderson DK, Waters TR, Kalaf L (1981) Effect of methylprednisolone in compression trauma to the feline spinal cord. J Neurosurg 55:200-208.

Mendel DB, Bodwell JE, Gametchu B, Harrison RW, Munck A (1986) Molybdate-stabilized nonactivated glucocorticoid receptor complexes contain a $90-\mathrm{kDa}$ non-steroid-binding phosphoprotein that is lost on activation. J Biol Chem 261:3758-3763.

Moynagh PN, Williams DC, O'Neill LA (1994) Activation of NF-kappa $\mathrm{B}$ and induction of vascular cell adhesion molecule-1 and intracellular adhesion molecule-1 expression in human glial cells by IL-1. Modulation by antioxidants. J Immunol 153:2681-2690.

Sanchez ER, Meshinchi S, Schlesinger MJ, Pratt WB (1987) Demonstration that the 90-kilodalton heat shock protein is bound to the glucocorticoid receptor in its $9 \mathrm{~S}$ nondeoxynucleic acid binding form. Mol Endocrinol 1:908-912.

Scheinman RI, Gualberto A, Jewell CM, Cidlowski JA, Baldwin AS Jr (1995) Characterization of mechanisms involved in transrepression of NF- $\kappa$ B by activated glucocorticoid receptors. Mol Cell Biol 15:943-953.

Tsai SY, Carlstedt-Duke J, Weigel NL, Dahlman K, Gustafsson JA, Tsai MJ, O'Malley BW (1988) Molecular interactions of steroid hormone receptor with its enhancer element: evidence for receptor dimer formation. Cell 55:361-369.

Vedeckis WV (1983) Subunit dissociation as a possible mechanism of glucocorticoid receptor activation. Biochemistry 22:1983-1989.

Visser DT, Hu Z, Pasterkamp RJ, Morimoto M, Kawata M (1996) The alteration of glucocorticoid receptor immunoreactivity in the rat forebrain following short-term and long-term adrenalectomy. Brain Res 729:216-222.

Wang CX, Nuttin B, Heremans H, Dom R, Gybels J (1996) Production of tumor necrosis factor in spinal cord following traumatic injury in rats. J Neuroimmunol 69:151-156.

Wang CX, Olschowka JA, Wrathall JR (1997) Increase of interleukin-1 mRNA and protein in the spinal cord following experimental traumatic injury in the rat. Brain Res 759:190-196.

Xu XM, Guenard V, Kleitman N, Bunge MB (1995) Axonal regeneration into Schwann cell-seeded guidance channels grafted into transected adult rat spinal cord. J Comp Neurol 351:145-160.

Xu XM, Chen A, Guenard V, Kleitman N, Bunge MB (1997) Bridging schwann cell transplants promote axonal regeneration from both the rostral and caudal stumps of transected adult rat spinal cord. J Neurocytol 26:1-16.

Xu J, Fan G, Chen S, Wu Y, Xu XM, Hsu CY (1998) Methylprednisolone inhibition of TNF- $\alpha$ expression and NF- $\kappa$ B activation after spinal cord injury in rats. Mol Brain Res 59:135-142.

Yakovlev AG, Faden AI (1994) Sequential expression of c-fos protooncogene, TNF-alpha, and dynorphin gene in spinal cord following experimental traumatic injury. Mol Chem Neuropath 23:179-190.

Yamamoto KR (1985) Steriod receptor regulator transcription of specific genes and gene networks. Annu Rev Genet 19:209-252.

Yan P, Li Q, Hsu CY, Xu J, He Y, Xu XM (1998) Expression of glucocorticoid receptor following spinal cord injury. Soc Neurosci Abstr 24:738.

Young W, Flamm ES (1982) Effect of high-dose corticosteroid therapy on blood flow, evoked potentials, and extracellular calcium in experimental spinal cord injury. J Neurosurg 57:667-673. 